\title{
Biodiversity and phenological status of the waterbirds of the Lac des Oiseaux (Northeast of Algeria)
}

\author{
F. Z. Boubekeur ${ }^{1}$, S. Setbel ${ }^{2}$, S. Atoussi ${ }^{3}$, M. Bara ${ }^{3}$, L. Bouaguel ${ }^{3,4}$, I. Houhamdi ${ }^{5}$, \\ A. Kerfouf ${ }^{1^{*}}$, M. Houhamdi ${ }^{3}$ \\ ${ }^{1}$ Laboratory of Spaces Eco-Development, Djillali Liabes University, Sidi Bel Abbes, 22000, Algeria \\ ${ }^{2}$ Department of Agronomic Sciences, Faculty of Natural and Life Sciences, University Mouloud Mammeri, \\ Tizi-Ouzou, Algeria \\ ${ }^{3}$ Department of Biology, Water and Environment Laboratory (LBEE), SNV-STU Faculty, University 8 May \\ 1945 Guelma. BP. 40124000 Guelma, Algeria \\ ${ }^{4}$ Department of Biology, Faculty of Natural and Life Sciences, Mohamed-Chérif Messaidia University of Souk \\ Ahras, Algeria. PO Box 1553, Annaba Road, Souk-Ahras. 41000, Algeria \\ ${ }^{5}$ Department of Biology, Faculty of Sciences, Badji Mokhtar University, Annaba, Algeria
}

\section{Corresponding author E-mail: kerfoufahmed@yahoo.fr}

\section{Received: 26.09.2020. Accepted: 26.10.2020}

\begin{abstract}
Counts carried out over two consecutive years (from September 2017 to August 2019) of waterbirds occupying the Lac des Oiseaux (Ramsar site, wilaya of El-Tarf, extreme north-eastern Algeria) showed a species richness estimated at 38 waterbird species belonging to 11 families. The Anatidae and Scolopacidae with 10 and 7 species respectively are the most families represented. The former are mainly observed during the wintering season and the latter during the summer period. From an effective point of view, Anatidae and Rallidae, mainly the Eurasian Coot Fulica atra are the most abundant. From a phenological point of view, eleven species are summering, ten are resident and wintering and eight are sporadic species.
\end{abstract}

Keywords: Phenology; Waterbirds; Wetland; Ecology; Lac des Oiseaux; Algeria

\section{Introduction}

Algeria has many little-known wetland complexes that are real sanctuaries for fauna and flora (Houhamdi, 1998). These wetlands are part of a vast Mediterranean eco-complex exploited by waterbird populations structured in metapopulations (Seddik et al., 2012, Hafid et al., 2014). The Lac des Oiseaux, a Ramsar site since 1999, is located in the extreme north-east of Algeria and is a preferential wintering and breeding ground for many waterbird species (Houhamdi, 2002).

Studies of the wintering strategy of waterbirds, their spatial and temporal patterns of occupancy and their diurnal behaviour remain among the major concerns in determining the ecological role that a site can play. Thus counts and regular monitoring are of great interest for understanding the structure and functioning of wetlands (Houhamdi and Samraoui, 2001, 2002, 2003, 2008). Our study carried out over two consecutive years (September 2017 to August 2019) is based on an inventory of all waterbirds that have frequented Lac des Oiseaux in order to determine their phenological status (wintering, sedentary, summering or sporadic species) and to define their diurnal use of this wetland.

\section{Site description}

Lac des Oiseaux ( $36^{\circ} 47^{\prime} \mathrm{N} 08^{\circ} 7^{\prime} \mathrm{E}$ ) has a more or less oval surface stretched to the northwest by a characteristic pond tail with shallow, shallowly sloping shores. It is a freshwater site and covers a total area of 70 ha with a deposit of $20 \mathrm{~cm}$ of organic matter (Figure 1 and Figure 2). The lake is an excellent wintering place for many birds, some of which are listed on the IUCN Red List, mainly the White-headed Duck Oxyura leucocephala, Ferruginous Duck Aythya nyroca and Sultan's Hen Porphyrio porphyrio (Houhamdi and Samraoui, 2002). The hydrological network of the lake is very slow. The vegetation belt is very diverse. About a hundred species have been identified, consisting mainly of grassy lawns (Cynodan dactylon, Paspalum distichum...), Asteraceae (Bellis anua, B. repens, Senecio vulgaris...), Juncus acutus, Asphodelus aestivus. In the wtlandr, we encounter fringes of Phragmites australis, Scipus lacustris, S. maritimus, Potamogeton luceus, Myriophylum spicatum.

The springs that feed it, because of the relatively gentle slopes, drain the water with difficulty towards the outlet. Similarly, several tributaries coming from the ridges of the watershed and whose flows are important in winter, drain their waters towards the basin, thus allowing the Lac des Oiseaux to have a positive water balance. As a result, this body of water dries up only occasionally (Houhamdi, 2002). Various pressures are exerted on the lake, threatening its ecological integrity.

\section{Materials and Methods}

The main objective of our study was to count all the waterbirds that have frequented the Lac des Oiseaux (Northeastern Algeria) during the period spanning two consecutive years, from September 2017 to August 2019, thus determining their wintering, 
summering, or breeding status. Counts were carried out twice a month using a long ornithological view (Konus Spot $20 \times 60$ ). An individual count was carried out when the group of birds numbered less than 200 individuals and was at a distance of less than 200 $\mathrm{m}$. Otherwise, i.e., if the group consists of more than 200 birds or is at a distance of more than $200 \mathrm{~m}$, we made an estimate (Baaziz et al., 2011). To do this, we divide the visual field into several bands of birds and count the number of birds in an average band and report as many times as there are bands. This technique has a margin of error of up to $10 \%$. It is closely related to the experience of the observer and the quality of the equipment used (Houhamdi and Samraoui, 2002, Amorabda et al., 2015, Merzoug et al., 2015).
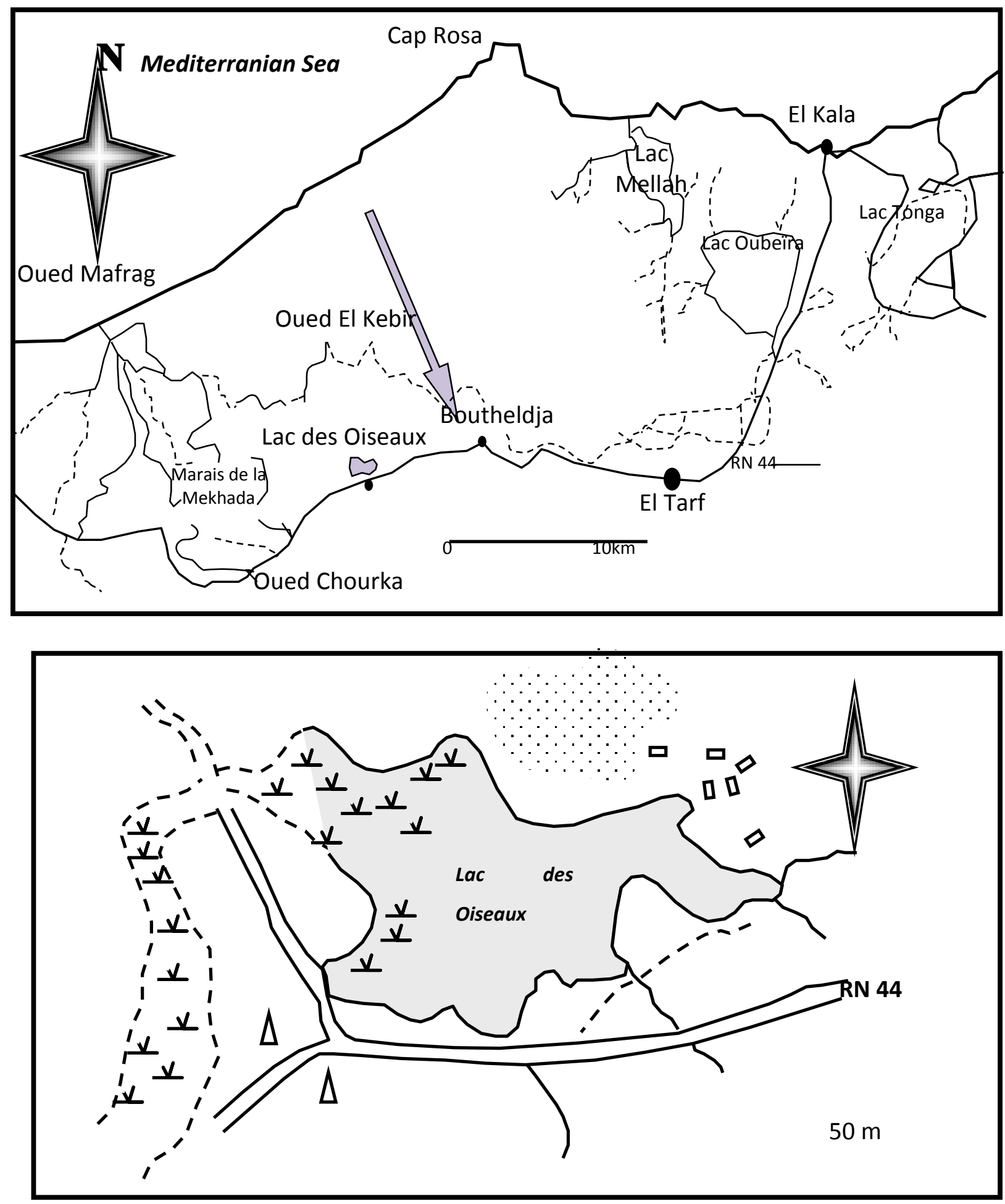

Figure 1. Location map of Lac des Oiseaux (Houhamdi, 1998). 


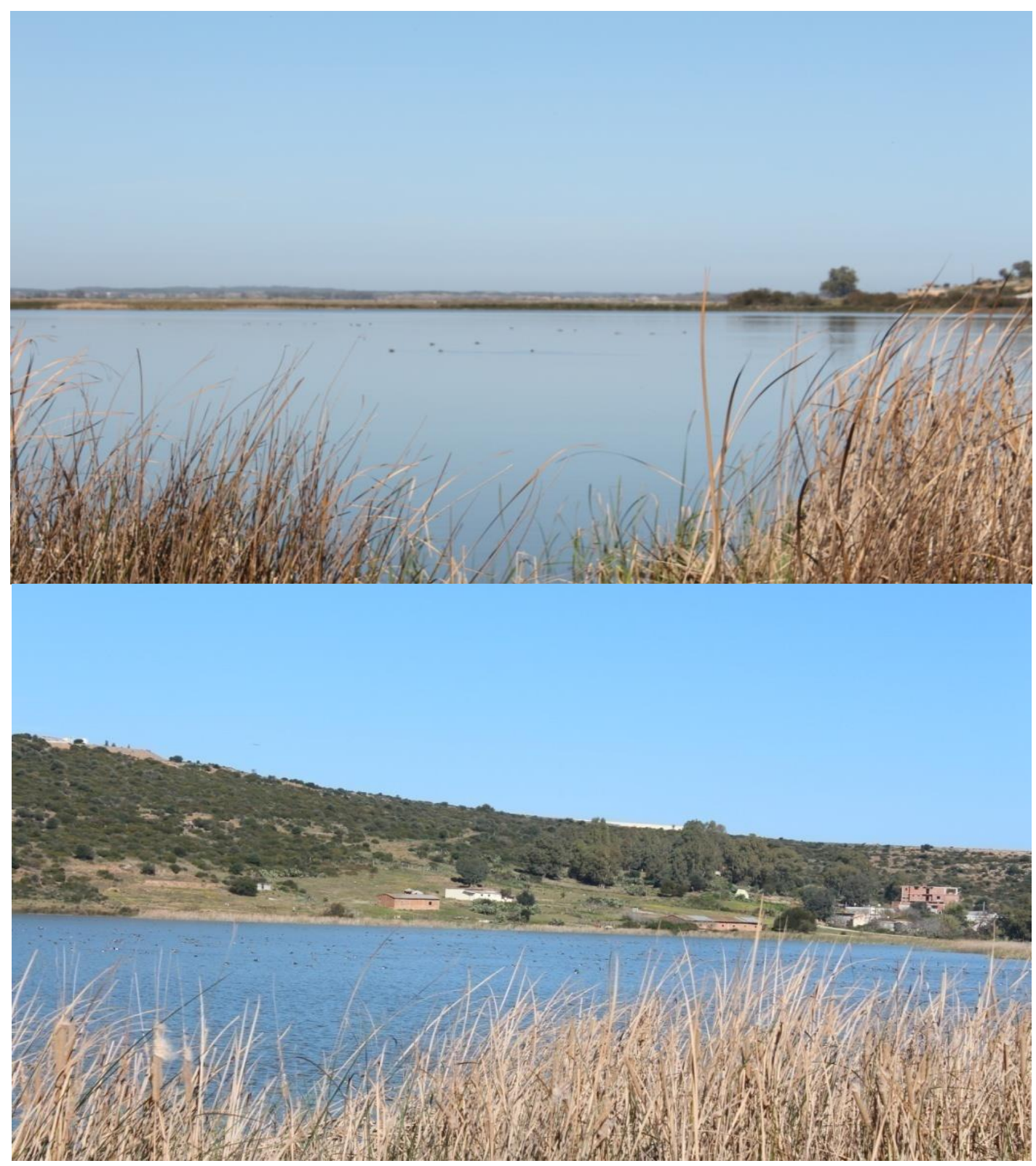

Figure 2. General views of the Lac des Oiseaux, (December 2018, Houhamdi).

\section{Results and Discussion}

Thirty-eight-seven species of waterbirds belonging to eleven families were recorded during the entire study period. They exhibit different phenological status (Figure 3). This richness is low compared to what was observed during the years 1996-2000, when fifty-eight species belonging to seventeen families were observed (Houhamdi, 2002, Houhamdi and Samraoui, 2002). This richness remains high compared to other Algerian wetlands (Metallaoui and Houhamdi, 2008, 2010, Seddik et al., 2010, Hafid et al., 2014, Bouzegag et al., 2014, Bendahmane et al., 2014, Beghdadi et al., 2016, Tabouche et al., 2016, Elafri et al., 2016a, 2016b, 2017, Atoussi et al., 2017).

The Podicipedidae familiy is represented by two species, the Little Grebe Tachybaptus ruficollis and the Great Crested Grebe Podiceps cristatus, both of which are sedentary breeders. They regularly nest in the lake but in small numbers. Their breeding period is from March to June. The chicks remain in the site until October.

The Phalacrocoracidae familiy is represented only by the Great Cormorant Phalacrocorax carbo, which is a seabird that regularly frequents the lake with a low population of no more than 10 birds.

The Ardeidae familiy is represented by four species (Figure 4). The Western Cattle Egret Ardea ibis and Little Egret Egretta garzetta which are nesting in the adjacent wetlands and regularly frequent the water body the Western Cattle Egret with 80-200 birds for resting and the Little Egret with a maximum recorded number of 9 birds foraging. The Great Egret Egretta alba and Grey Heron Ardea cinerea are two wintering species. They are generally observed alone in the water near the banks.

The Threskiornidae family is represented by the Eurasian Spoonbill Platalea leucorodia and the Glossy Ibis Plegadis falcinellus, are very common in Algeria (Boudraa et al., 2014, 2015) and they are observed in small groups (5 and 8 birds) during the months of November and December in the muddy areas of the lake looking for food.

The Ciconiidae family is represented by only one species (Figure 4), the White Stork Ciconia ciconia, which frequents the lake from January to August with a very low number (2-4 birds).

The Anatidae family is the most represented in Algeria (Boukrouma et al., 2011, Chettibi et al., 2014, Metallaoui et al., 2009, 2014, Bendahmane et al., 2014, Aberkane et al., 2014, Lardjane-Hamitti et al., 2014, 2015, Halassi et al., 2016, Beghdadi et al., 2016, Abdi et al., 2016, Elafri et al., 2016a, 2016b, 2017, Bouchaala et al., 2017, Oudihat et al., 2017, Khemis et al., 2017a, 2017b, Charchar et al., 2019, Bezzala et al., 2019a, 2019b) and in the lake (Figure 4). The Ferruginous Duck Aythya nyroca and the Whiteheaded Duck Oxyura leucocephala, Mallard Anas platyrhynchos, are regular sedentary nesting species in the Lac des Oiseaux. The 
first two are listed in the IUCN Red List and have a special protection status (Atoussi et al., 2017, Guellati et al., 2014, Houhamdi et al., 2008). The maximum recorded numbers for these three species are 350 birds for the Ferruginous Duck, 9 individuals for the White-headed Duck and 108 individuals for the Mallard. The seven other species observed (Gadwall Anas strepera, Eurasian Wigeon Anas penelope, Eurasian Teal Anas crecca crecca, Northern Pintail Anas acuta, Northern Shoveler Anas clypeata, Marbled Teal Marmaronetta angustirostris and Common Pochard Aythya ferina) have a phenological status of wintering species. Their numbers generally fluctuate between 350 and 600 birds.

The Rallidae family is represented by three species, the Eurasian Coot Fulica atra, the Common Moorhen Gallinula chloropus and the Western Swamphen Porphyrio porphyrio (Figure 4). All three species are regular breeders in the Lac des Oiseaux. They nest in the tufts of Phragmites australis, Typha angustifolia and Scirpus maritimus bordering this wetland. It should be noted that the Western Swamphen is listed on the IUCN Red Lite and in terms of abundance, the Eurasian Coot is the most abundant waterbird in the site. Its numbers can reach 1500 birds.

The Recurvirostridae family is also represented by two species that frequent the banks of this wetland only during the summer period (Figure 4), the Black-winged Stilt Himantopus himantopus and the Pied Avocet Recurvirostra avosetta. They are noted on the banks with low numbers not exceeding 20 birds.

The Charadriidae family is represented by three species, two of which are summering (Common Ringed Plover Charadrius hiaticula, Little Ringed Plover Chub Charadrius dubius) and one wintering (Northern Lapwing Vanelluls vanellus) (Figure 4). All three species frequent the shores and muddy areas of the lake. The Ruffed Lapwing is the most represented. Its numbers reach 120 birds.

The Scolopacidae family is represented by seven species: the Curlew Sandpiper Calidris ferruginea, Dunlin Calidris alpina, Little Stint Calidris minuta, Black-tailed Godwit Limosa limosa, Common Greenshank Tringa nebularia, Spotted Redshank Tringa erythropus, and Common Redshank Tringa totanus (Figure 4). The first three are habitual overwinterers in the lake. They are recorded with low numbers of no more than 20 individuals. The Black-tailed Godwit is the only wintering species and the most abundant. It is recorded with numbers fluctuating between 30 and 40 birds. The two Redshanks are mainly observed during their post-migration passages (transits) with very limited numbers generally not exceeding 5 individuals. The same findings have been observed in other Algerian wetlands (Elafri et al., 2017, Baaziz et al., 2011, Seddik et al., 2010, 2012).

The Laridae family is very poorly represented in this wlake (Figure 4). Three species are observed, the Yellow-legged Larus cachinnans, and the Black-headed Gull Chroicocephalus ridibundus and the Whiskered Tern Childonias hybridus. These three species have a rare species status and are only observed for a short period of time. Their numbers are very low ( 2 to 5 birds).

\section{Conclusion}

Our work was focused on the level of infestation within the two experimental stations where we found 5 species of Homoptera subservient to the olive tree in the région of Blida by treating the population dynamics of the 3 main cochineals (Pollinia pollini, Octaspidiotus nerii, Saissetia oleae), through observation of twigs and leaves.

During the study period, the influence of concomitant factors (climatic conditions, cultivation practices, phenomena related to the biology of the pest, plot environment, etc.) on the level of infestation of coccids between two olive groves (Soumaa and Guerrouaou). Despite the lack of data on these 3 scale insects. We can deduce that $P$. pollini is a heliophilic species, specific to the olive tree and which overwinters at the young female and adult female stage. $P$. pollini develops in 2 annual generations: a spring generation and a summer generation. The larval stage is the most abandoned compared to the other stage of development. The south orientation seems to be the most popular with $P$. pollini. The spring period is favored by the rise in temperature and the vegetative awakening, the laying begins during this period. The population of Octaspidiotus nerii occurs in a single generation, and if conditions are favorable it can develop a second generation. It appears that the study of the biology of 0 . nerii allowed us to conclude that she has two generations; spring and autumn depending on climatic factors. The East and West exposure represent the rights most sought after by this mealybug, where relative abundance has been found between larvae and adult females. Seasonal climatic conditions and the host plant are a factor regulating the evolution of this diaspin: spring is the most favorable season for the outbreak of $O$. nerii. The results mentioned allowed us to estimate that $S$. oleae develops only one generation per year (autumn generation). The $\mathrm{H}$ cochineal has a more or less marked affinity for the east orientation for the different stages of development, while the females are most abundant in the Soumaa station and the larvae at the Guerrouaou station. The east orientation and the spring season are the most favorable for the development of the cochineal.

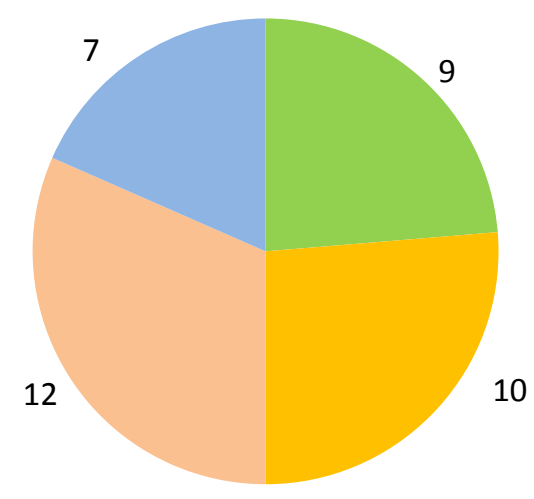

Summer species $\square$ Residents species $\square$ Wintering species $\square$ Sporadic species

Figure 3. Phenological status of waterbirds at Lac des Oiseaux (from 2017 to 2019). 


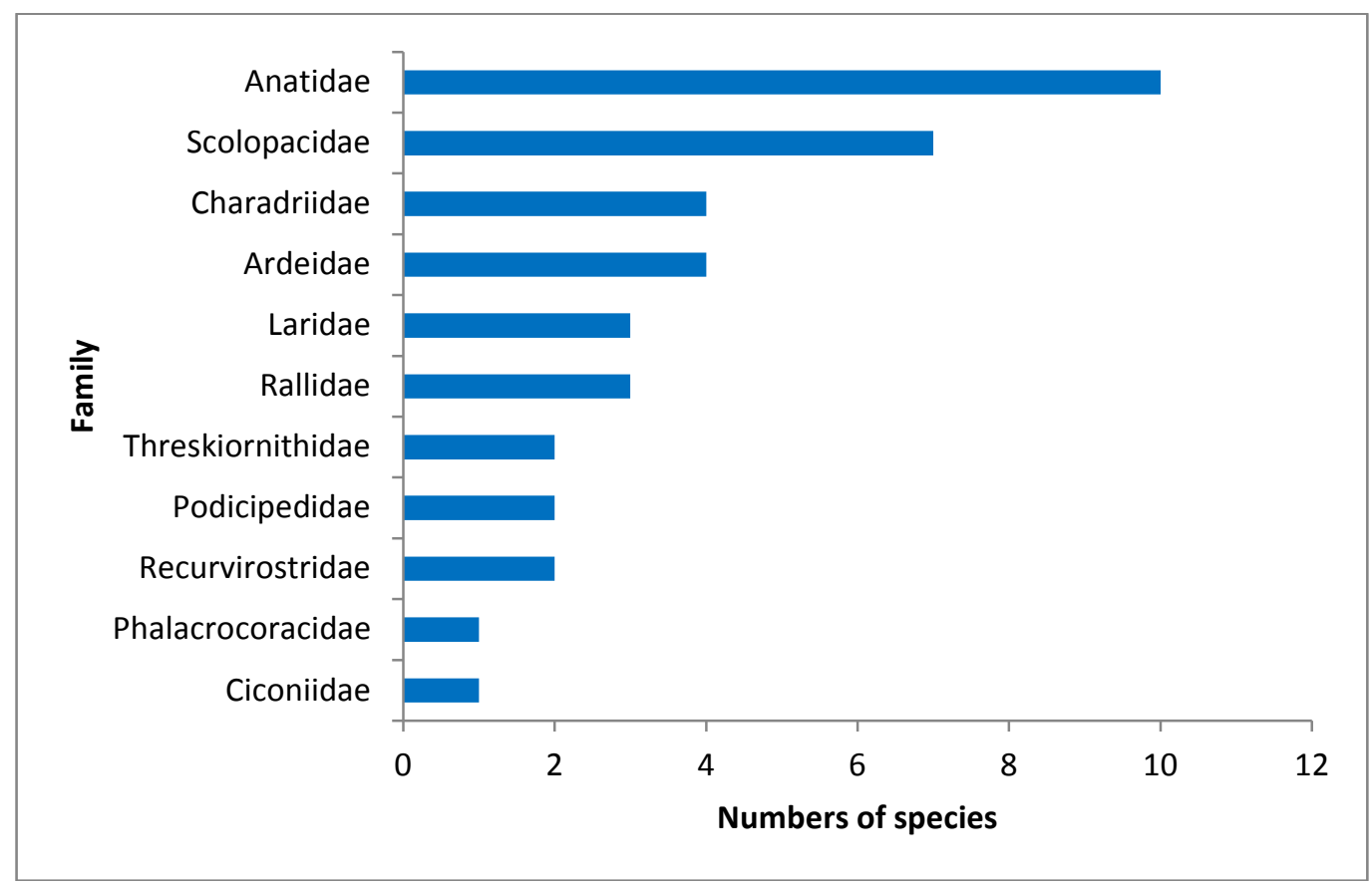

Figure 4. Species richness of waterbirds from different families during the study period at Lac des Oiseaux (from 2017 to 2019 ).

\section{Conclusion}

During our two-year study (2017-2019) we counted 38 species of waterbirds belonging to 11 families. This aquatic avifauna distributes itself in the Lac des Oiseaux in different ways that are often erected by quietness, security and food availability. We record 10 sedentary species, 12 wintering species, 09 summering species and 07 sporadict species that only frequent Lac des Oiseaux during small periods (migratory transit periods). The most represented family is the Anatidae with ten species of which three are regular breeders. It is followed by the Scolopacidae family with seven species but a rather low representativeness. They occupy the banks of the lake and show, along with the other shorebirds (Black-winged Stilt and Pied Avocet), a very high level of feeding activity. The Eurasian Coot (Rallidae) has the highest population in this wetland (1500 individuals). The lake's helophytes (Typha angustifolia, Phragmites australis and Scirpus maritimus) take a essential rôle in the maintenance of the nesting aquatic avifauna. It constitutes a shelter and a nesting place.

\section{Aknowledgements}

This work was supported by DGRSDT and MESRS of Algeria (CNEPRU project). We are pleased to thinks all persons which contributed to help us in order to finish this works, especially M. Abdelatif Gasmi.

\section{References}

Abdi S., Merzoug S., Tabouche K., Maazi M-C. and Houhamdi M. (2016). Structure des effectifs et stationnement hivernal du Fuligule nyroca Aythya nyroca dans le complexe de zones humides de Guerbes-Sanhadja (Nord-est algérien). Bulletin de la Société Zoologique de France. 141(2): 91-102.

Aberkane M., Maazi M-C., Chettibi F., Guergueb E., Bouslama Z. and Houhamdi M. (2014). Diurnal wintering behaviour of the Marbled Teal (Marmaronetta angustirostris) in north-east Algeria. Zoology and Ecology 4(1): 1-6.

Amorabda W., Merzoug S., Belhamra M. and Houhamdi M. (2015). Phenology and diurnal behaviour of the Northern Shoveler Anas clypeata in the Guerbes-Sanhadja wetland complex (north-eastern Algeria). Zoology and Ecology, 25(1): 1-8.

Atoussi S., Rezkallah I., Khemis MDE., Merzoug A., Telailia S. and Houhamdi M. (2017). Nouvelles données sur I'hivernage del'Erismature à tête blanche Oxyura leucocephala en Algérie. Alauda. 85(1): 29-36.

Baaziz N., Mayache B., Saheb M., Bensaci E., Ounissi M., Metallaoui S. and Houhamdi M. (2011). Statut phénologique et reproduction des peuplements d'oiseaux d'eau dans l'éco-complexe de zones humides de Sétif (Hauts plateaux, Est de l'Algérie). Bulletin de I'Institut Scientifique de Rabat. 32(2): 77-87.

Beghdadi F., Saheb M., Mayache B., Nouidjem Y., Bensaci E., Bouzegag A., Guergueb E., Oudihat K. and Houhamdi M. (2016). Le Flamant rose Phœnicopterus roseus dans l'ouest algérien : tentative de nidification échouée dans le Chott Ech-Chergui (El-Bayadh). Bulletin de la Société Zoologique de France. 141(2): 81-90.

Bendahmane I., Mostefai N., Moulai-Melliani K. and Houhamdi M. (2014). Statut phénologique de la famille des Anatidés dans la zone humide de Dayet El-Ferd, Tlemcen (Algérie). Bulletin de la Société Zoologique de France, 139(1-4): 83-89.

Benradia M., Menaa M., Guellati K., Maazi M-C., Bouslama Z. and Houhamdi M. (2018). Premières données sur les Anatides et les Foulques macroules fulica atra dans les zones humides de la wilaya de Souk-ahras (extreme nord-est de l'algerie). Bulletin de la Société Zoologique de France 143(3): 145-169.

Bensizrara D., Chenchouni H., Sibachir A. and Houhamdi M. (2013). Ecological status interactions for assessing bird diversity in relation to a heterogeneous landscape structure. Avian Biology Research 6 (1): 67-77.

Bezzala A., Houhamdi M. and Chenchouni H. (2019). Bird ecological status of two internationally important wetlands 'Ramsar sites and IBA' in Algeria. Estuarine, Coastal and Shelf Science. $227: 1-10$.

Bezzala A., Houhamdi M., Maazi M-C. and Chenchouni H. (2019). Modeling climate influences on population dynamics and diurnal time-budget of the Shelduck (Tadorna tadorna) wintering in Ramsar wetlands of Algeria. Avian Biology Research. 11(4) : 1-8. 
Bouchaala L., Elafri A., Charchar N., Boukhemza M. and Houhamdi M. (2017). Wintering behaviour and spatial ecology of Eurasian Wigeon Anas penelope in a coastal Mediterranean wetland complex (Guerbes-Sanhadja) of northeastern Algeria. Avian Biology research 10(2): 84-91.

Boudraa W., Bouslama Z. and Houhamdi M. (2014). Inventaire et écologie des oiseaux d'eau dans le marais de Boussedra (Annaba, nord-est de l'Algérie). Bulletin de la Société Zoologique de France, 139 (1-4) : 279-293.

Boudraa W., Bara M., Khemis MEH., Boumaaza O., Bouslama Z. and Houhamdi M. (2015). Nidification réussie de I'Ibis Falcinelle Plegadis falcinellus dans un milieu humide urbain en Algérie. Alauda 83(2): 143-148.

Boukrouma N., Maazi M-C., Saheb M., Metallaoui S. and Houhamdi M. (2011). Hivernage du Canard Pilet Anas acuta sur les hauts plateaux de l'Est de l'Algérie. Alauda 79(4): 285-293.

Bouzegag A., Saheb M., Bensaci E., Nouidjem Y. and Houhamdi M. (2013). Ecologie de la Sarcelle Marbrée Marmaronetta angustirostris dans l'éco-complexe de zones humides de la vallée de l'oued Righ (Sahara algérien). Bulletin de I'Institut Scientifique de Rabat. 35: 141-149.

Charchar N., Bouchaâla L. and Houhamdi M. (2019). Phenology and diurnal behavior of marbled duck Marmaronetta angustirostris in the eco-complex of wetlands of Guerbes Sahhadja North-east of Algeria. Ecologia mediterranea 45 (2): 35-43.

Chettibi F., Khelifa R., Aberkane M., Bouslama Z. and Houhamdi M. (2013). Diurnal activity budget and breeding ecology of WhiteHeaded Duck Oxyura leucocephala at Lac Tonga (North-east Algeria). Zoology and Ecology 23(3): 183-190.

Elafri A., Halassi I. and Houhamdi M. (2016)a. Diversity patterns and seasonal variation of the waterbird community in Mediterranean wetlands of Northeastern Algeria. Zoology and Ecology 26(1): 9-14.

Elafri A., Halassi I. and Houhamdi M. (2016)b. Time budget patterns and complementary use of a Mediterranean wetland (Tonga, North-east Algeria) by migrant and resident waterbirds. Rivista Italiana di Ornitologia - Research in Ornithology, 86 (1): 55-6426.

Elafri A., Belhamara M. and Houhamdi M. (2017). Comparing habitat preferences of a set of waterbird species wintering in the coastal wetlands of North Africa: implication for management. Ekológia (Bratislava), 86 (1): 170-183.

Guellati K., Maazi M-C., Benradia M. and Houhamdi M. (2014). Le peuplement d'oiseaux d'eau du complexe des zones humides de la wilaya de Souk-Ahras : état actuel et intérêt patrimonial. Bulletin de la Société Zoologique de France, 139 (1-4) : 263-277.

Guergueb E., Bensaci E., Nouidjem Y., Zoubiri A., Kerfouf A. and Houhamdi M. (2014). Aperçu sur la diversité des oiseaux d'eau du chott El-Hodna (Algérie). Bulletin de la Société Zoologique de France, 139 (1-4) : 233-244.

Hafid H., Hanane S., Saheb M. and Houhamdi M. (2013). Dynamique spatio-temporelle de I'hivernage de Grues cendrées Grus grus en Algérie. Alauda 81(3): 201-208.

Halassi I., Elafri A., Belhamra M. and Houhamdi M. (2016). Répartition et abondance de l'Erismature à tête blanche Oxyura leucocephala dans les zones humides du Nord-Est algérien. Alauda 84(1): 23-32.

Houhamdi M. (1998). Ecologie du Lac des Oiseaux: Cartographie, Palynothèque et utilisation de l'espace par I'avifaune. Magister Thesis, University Badji Mokhtar Annaba, Algeria. 165p.

Houhamdi M. (2002). Ecologie des peuplements aviens du Lac des Oiseaux (Numidie orientale). PhD Thesis, University Badji Mokhtar Annaba, Algeria. 133p.

Houhamdi M. and Samraoui B. (2001). Diurnal time budget of wintering Teal Anas crecca crecca L. at Lac des Oiseaux, northeast Algeria. Wildfowl. 52: 87-96.

Houhamdi M. and Samraoui B. (2002). Occupation spatio-temporelle par I'avifaune aquatique du Lac des Oiseaux (Algérie). Alauda. 70 (2): 301-310.

Houhamdi M. and Samraoui B. (2003). Diurnal behaviour of wintering Wigeon Anas penelope in Lac des Oiseaux, northeast Algeria. Wildfowl. 54: 51-62.

Houhamdi M. and Samraoui B. (2008). Diurnal and nocturnal behaviour of Ferruginous Duck Aythya nyroca at Lac des Oiseaux, northeast Algeria. Ardeola 55 (1): 59-69.

Khemis MEH., Hanane S., Telailia S., Elafri A., Boumaaza O., Boucherit K., Amari H. and Houhamdi M. (2017). Activity patterns in two sympatric duck species in a Méditeranean remnant wetland: Prformance; seasonal variability and implications. Vie \& milieu (Life and Environment) 67(3-4): 209-2016.

Lardjane-Hamiti A., Metna F.A, Boukhemza M., Merabet S. and Houhamdi M. (2015). Variation in the Diet of Common Moorhen Gallinula chloropus (Aves, Rallidae) at Lake Réghaïa, Algeria. Zoology and Ecology 5(2): 1-8.

Lardjane-Hamiti A., Metna F., Merabet S., Rakem K., Boukhemza M. and Houhamdi M. (2013). Quelques aspects éthologiques du Fuligule nyroca Aythya nyroca (Anatidae) dans la réserve naturelle du lac de Reghaia (Algérie). Bulletin de la Société Zoologique de France. 138(1-4): 103-113.

Merzoug A., Bara M. \& Houhamdi M. (2015). Diurnal time budget of Gadwall Anas strepera in Guerbes-Sanhadja wetlands (Skikda, northeast Algeria). Zoology and Ecology 5(2): 101-105.

Metallaoui S. and Houhamdi M. (2008). Données préliminaires sur l'avifaune aquatique de la Garaet Hadj-Tahar (Skikda, Nord-Est algérien). Afri. Bird Club Bull. 15(1): 71-76.

Metallaoui S. and Houhamdi M. (2010). Biodiversité et écologie de l'avifaune aquatique hivernante dans Garaet Hadj-Tahar (Skikda, Nord-Est de I'Algérie). Hydroécologie Appliquée. 17: 1-16.

Metallaoui S., Atoussi S., Merzoug A. and Houhamdi M. (2009). Hivernage de l'Erismature à tête blanche Oxyura leucocephala dans Garaet Hadj-Tahar (Skikda, Nord-Est de l'Algérie). Aves. 46(3): 136-140.

Metallaoui S., Maazi M-C., Saheb M., Houhamdi M. and Barbraud C. (2014). A comparative study of the diurnal behaviour of the Northern Shoveller (Anas clypeata) during the wintering season at Garaet Hadj-Tahar (North-East Algeria) and Garaet Timerganine (Algerian highlands). Turkich Journal of Zoology (38): 1-10.

Khemis MEH., Boumaaza O., Bensaci E., Amari H., Boucherit K., Elafri A., Hanane S., Bouslama Z. \& Houhamdi M. (2017). Diurnal behavior and pairing chronology of the Northern Shoveler wintering in unprotected remnant wetlands of north-eastern Algeria. Zoology and Ecology. 27(1): 11-18.

Oudihat K., Moulaï R. and Houhamdi M. (2017). Phenologie et budget temps diurne en période hivernale de la Nette rousse (Netta rufina) et de l'Erismature à tête blanche (Oxyura leucocephala) à Dayet El-Ferd (Nord-ouest algérien). Bulletin de la Société Zoologique de France. 142(2): 49-62.

Seddik S., Bouaguel L., Bougoudjil S., Maazi M-C., Saheb M., Metallaoui S. and Houhamdi M. (2012). L'avifaune aquatique de la Garaet de Timerganine et des zones humides des Hauts Plateaux de l'Est algérien. Afri. Bird Club Bull. 19(1): 25-32. 
Seddik S., Maazi M-C., Hafid H., Saheb M., Mayache B. and Houhamdi M. (2010). Statut et écologie des peuplements Laro-Limicoles et Echassiers dans les zones humides des hauts plateaux de l'Est de l'Algérie. Bulletin de I'Institut Scientifique de Rabat. 32(2): 111118.

Tabouche K., Merzoug S., Abdi S., Maazi M-C. and Houhamdi M. (2016). Hivernage du Canard souchet Anas clypeata dans Garaet Hadj-Tahar (Algérie). Bulletin de la Société Zoologique de France. 141(2): 109-120.

\section{Citation:}

Boubekeur, F.Z., Setbel, S., Atoussi, S., Bara, M., Bouaguel, L., Houhamdi, I., Kerfouf, A., Houhamdi, M. (2020). Biodiversity and phenological status of the waterbirds of the Lac des Oiseaux (Northeast of Algeria). Ukrainian Journal of Ecology, 10(5), 69-75. 